\title{
RECQL4 Gene
}

National Cancer Institute

\section{Source}

National Cancer Institute. RECQL4 Gene. NCI Thesaurus. Code C26492.

This gene is involved in the initiation of DNA replication and sister-chromatid cohesion. 